\title{
Perception of farmers about endometritis prevention and control measures for zero- grazed dairy cows on smallholder farms in Rwanda
}

Pascal Nyabinwa ${ }^{1,2^{*}}$ (D), Olivier Basole Kashongwe ${ }^{2}$, Claire d'Andre Hirwa ${ }^{1}$ and Bockline Omedo Bebe ${ }^{2}$

\begin{abstract}
Background: Endometritis is a prevalent uterine disease in postpartum cows. The disease reduces fertility performance and milk yield, and subsequently, productivity and profitability of dairy farms. The reduction in performance is associated with considerable economic losses on dairy farms. Smallholder farmers are likely to incur considerable economic losses from the disease where they lack knowledge of effective prevention and control measures for the disease. This study used farmer's perspectives to determine the effectiveness of different management interventions (Mls) for endometritis prevention and control on smallholder farms in Rwanda practicing dairy zero-grazing. The best-worst scaling (BWS) choice method was applied that relied on past 1 year recall data obtained from 154 farmers. These farmers were identified through snowball sampling in a cross-sectional study.

Results: Of the 20 Mls evaluated, 12 scored highly for effectiveness. The top four most effective are: avoiding sharing equipment with neighbouring farms (45.5\%), consulting animal health service provider about disease treatment (31.8\%), keeping cows in a clean and dry shed (26.7\%), and selecting sires based on calving ease (26.6\%). The Mls considered least effective were: maintaining clean transition cow housing (35.1\%), removal of fetal membrane immediately after passing (33.1\%), disinfecting the equipment used in calving assistance before and after use (32.5\%), and selecting sires with low percent stillbirths (29.2\%).

Conclusion: This study has demonstrated the application of BWS object case method in understanding the Mls that farmers consider are most effective in the prevention and control of endometritis disease in the dairy herds. The Mls are on-farm biosecurity and hygiene, seeking veterinary services for disease treatment and selecting sires for ease of calving. These Mls should be considered for prioritization in extension services and research to continuously improve and enhance their practical application on smallholder dairy farms.
\end{abstract}

Keywords: Herd health, Best-worst scaling choice, Extension messages, Management interventions, smallholder farmers

\footnotetext{
* Correspondence: nyabpass@gmail.com

${ }^{1}$ Rwanda Agriculture and Animal Resources Development Board, P.O; Box 5016, Kigali, Rwanda

${ }^{2}$ Department of Animal Sciences, Faculty of Agriculture, Egerton University,

P.O; Box 536, Egerton, Kenya
}

(c) The Author(s). 2020 Open Access This article is licensed under a Creative Commons Attribution 4.0 International License, which permits use, sharing, adaptation, distribution and reproduction in any medium or format, as long as you give appropriate credit to the original author(s) and the source, provide a link to the Creative Commons licence, and indicate if changes were made. The images or other third party material in this article are included in the article's Creative Commons licence, unless indicated otherwise in a credit line to the material. If material is not included in the article's Creative Commons licence and your intended use is not permitted by statutory regulation or exceeds the permitted use, you will need to obtain permission directly from the copyright holder. To view a copy of this licence, visit http://creativecommons.org/licenses/by/4.0/ The Creative Commons Public Domain Dedication waiver (http://creativecommons.org/publicdomain/zero/1.0/) applies to the data made available in this article, unless otherwise stated in a credit line to the data. 


\section{Background}

Dairy production is a major component in the livestock sector in Rwanda. The dairy subsector is an essential source of livelihood to over $80.0 \%$ of households involved directly or indirectly throughout the agricultural value chain [1]. The dairy subsector contributes $28.0 \%$ to the agricultural Gross Domestic Product (GDP) and $4.0 \%$ to the national GDP [2]. Rwanda has an estimated cattle population of $1,340,792$, of which $45.0 \%$ are indigenous cattle, $33.0 \%$ are dairy crossbreds, and $22.0 \%$ are pure dairy breeds [3]. The dairy crossbreds and pure dairy breeds are of the Friesians, Jersey, and Fleckvieh breeds. Among the smallholder dairy farms, those practicing zero-grazing hold the majority $(92.0 \%)$ of the cattle population and supply the bulk of the domestic milk market demand. However, the supply has not satisfied the local demand. The per capita milk consumption estimates by the Rwanda Livestock Master Plan [1] is 63.01 per person per annum. An increase of 3.5 fold would be necessary so as to achieve per capita consumption threshold of 2201 recommended by the Food and Agriculture Organization of the United Nations [4]. The low per capita milk consumption is to a large extent due to low productivity of the national herd, and this is attributable to suboptimal fertility performance of zero-grazed cows in smallholder dairy farms [5-7].

One disease associated with suboptimal fertility, though often unnoticed, is endometritis disease $[8,9]$. Endometritis is a disease of dairy cows occurring between the 21st and 90th days postpartum. The contamination of uterus by endometrial microbiota occurs at all stages of the reproduction cycle [10], but the majority of cases are found mostly during the first 2 weeks of postpartum [11]. This contamination is attributed to the fluctuation and expansion of the microbial community diversity after calving. The reason for this is because of the dilation of physical barriers such as vulvar sealing, vestibule-vaginal constriction, the cervix, cervicovaginal mucus secretion, and the epithelial barrier. These allow contamination and colonization of the genital tract with pathogenic bacteria from the environment, skin, faeces, and vagina [12]. These pathogenic bacteria such as Escherichia coli, Fusobacterium necrophorumand Staphylococcus aureus are the common causes of endometritis in dairy cattle [13]. The di, sease results in considerable economic losses through the reduction in production and fertility performance, culling of cows, and veterinary costs $[8,9]$.

Good management practices in the pre-and postpartum period can minimize or even avoid cow uterine infections and prevent the prevalence of endometritis disease [14]. In contrast, suboptimal management of transition cows exposes susceptible cows to postpartum uterine diseases in which endometritis is of importance [10, 12]. Sadly, effective treatment options for endometritis remain limited, yet the disease can persist even after treatment and recovery $[15,16]$. This means that treating the condition is not a solution; it is necessary to implement effective prevention and control measures $[12,14]$. Management interventions (MIs) that prevent the introduction and reduce the spread of disease-causing agents into and off the herd are critical components of the herd health program [17-19].

The MIs could significantly minimize endometritis incidences and consequently improve animal welfare and increase productivity and profitability of dairy herds [18]. This is supported by observations that improved extension service and advisory support in the pre- and postpartum periods improve the prevention and control of endometritis in the dairy herds [20]. In extension service delivery, farmers are essential in implementing MIs and evaluating the effectiveness of the different MIs for disease prevention and control $[18,21]$.

The best-worst scaling (BWS) choice is a preferred technique to gather opinions from different experts on the effectiveness of varying biosecurity measures on dairy farms [21, 22]. The BWS has been used in market research [23]; human health [24]; agriculture [25], and livestock management science [26, 27].

The literature search revealed no application of BWS choice to endometritis management studies. Empirical evidence on how dairy farmers perceive the effectiveness of MIs for endometritis prevention and control is yet to be documented. However, BWS holds great potential in determining effective MIs from farmers' perspectives; they are the implementers. Advances in this knowledge gap would be informative to actors in the dairy sector towards reducing the prevalence rate of endometritis disease in the dairy herds. In particular, extension service and farmers stand to benefit from the immediate application of effective MIs.

In Rwanda, smallholder dairy zero-grazing is a priority development intervention towards hunger eradication and attaining food and nutrition security [1]. High prevalence of endometritis in the herd could, however, impede the achievement of these development goals due to the economic loss associated with the disease. For this reason, this study evaluated the opinion of farmers about the effectiveness of different MIs for endometritis prevention and control under field conditions in Rwanda. The research will inform prioritization of MIs in extension service and for on-farm implementation.

\section{Results}

Socio-economic characteristics of the dairy farmers

The socio-economic characteristics of the sample farmers in the study area are presented in Table 1. The sampled farmers were between 25 and 85 years old and on average, were of middle-aged ( $41.5 \pm 1.1$ years) with an average of $9.6 \pm 0.5$ years of dairy farming experience. The majority 
Table 1 Socio-economic characteristic of the sample smallholder dairy farmers $(n=154)$

\begin{tabular}{llll}
\hline Variables & Frequency (\%) & Mean \pm S.E. & Min - Max \\
\hline Gender & & & \\
$\quad$ Male (\%) & 71.4 & & \\
$\quad$ Female (\%) & 28.6 & & \\
Educational level & & & \\
$\quad$ No schooling (\%) & 33.8 & & \\
Primary (\%) & 48.7 & & \\
Secondary (\%) & 14.9 & & \\
$\quad$ University (\%) & 2.6 & & \\
Poverty level & & & \\
$\quad$ Very poor (\%) & 8.4 & & \\
Poor (\%) & 63.0 & $25-85$ \\
Rich (\%) & 28.6 & $41.5 \pm 1.1$ & $1-9$ \\
Age (years), & & $9.6 \pm 0.5$ & $1-4$ \\
Dairying experience (years) & & $5.0 \pm 0.1$ & $0.6-7.4$ \\
Household size (number) & & $2.9 \pm 0.8$ & $3.8 \pm 0.1$ \\
Herd size (number) & & & \\
Farm size (acres), & & & \\
\hline
\end{tabular}

were males (71.4\%). About half had attained primary level education $(48.7 \%)$ while a few had attained secondary (14.9\%) or university (2.6\%) level education. However, over a third had not acquired any formal education (33.8\%). The family size was, on average, 5.0 \pm 0.1 members in a household. By poverty classification of the Rwanda government, farmers in the category of poor (63.0\%) dominated over those in the category of wealthy farmers (28.6\%). On average, a household kept a herd of less than 3 cattle on a farm of less than 4 acres (Table 1 ).

The herds were predominantly crossbreeds (63.6\%) with some pure breeds (29.0\%), and indigenous cattle breeds (7.4\%) kept to provide milk for domestic consumption, sale, and to provide manure for fertilizing the farms. The cows were kept in zero-grazing housing units, on the cutand-carry feeding system, with over half servicing with bulls $(53.9 \%)$. At the time of this study, the breeding services were at a cost: $\$ 5.6$ per service when using artificial insemination service and $\$ 3.3$ per service when using bull service. Dairy farmers sourced animal health services (ANHS) from veterinarians (VETs) (39.6\%), communitybased animal health workers (CAHWs) $(37.7 \%)$, and local traditional herbalists (LTHs) $(22.7 \%)$. The animal recording was not practiced (78.6\%) or incomplete (21.4\%).

The flooring of cattle shed was typically earthen (90.3\%), and only a few had concrete (9.7\%). Bedding materials were natural green grasses $(85.5 \%)$, and the leftovers or waste feeds from feeding troughs (14.5\%) (Table 2). The frequency of removal of leftovers or waste feeds was, on average, twice a week.
Table 2 Herd characteristics in the study area $(n=154)$

\begin{tabular}{llll}
\hline Characteristics & Level & Frequency (\%) & $\begin{array}{l}\text { Chi-square } \\
\text { test Sign }\end{array}$ \\
\hline Cattle shed flooring & Earthen & 90.3 & $* * *$ \\
& Concrete & 9.7 & \\
Types of cattle shed & With a roof & 65.6 & $* * *$ \\
& Without a roof & 34.4 & NS \\
Breeding services & Artificial insemination & 46.1 & \\
& service & & $* * *$ \\
& Bull service & 53.9 & \\
Herd record keeping & Incomplete & 21.4 & 78.6 \\
& Not practiced & & \\
\hline
\end{tabular}

NS Not significant $(p>0.05),{ }^{* * *} p<0.001$

\section{Effectiveness of the management interventions}

Figure 1 shows the percentage of MIs that farmers considered the most effective, least effective, and not considered the most or least effective. In decreasing order of probability of being considered most effective, the top four MIs were: avoiding equipment-sharing with neighbouring farms (45.5\%), consulting ANHS provider about the treatment of endometritis positive case (31.8\%), keeping cows in a clean and dry shed (26.7\%), and selecting sires based on calving ease (26.6\%). The MIs considered least effective were: maintaining clean transition cow housing (35.1\%), removal of fetal membrane immediately after passing (33.1\%), disinfecting calving assistance's equipment before and after use (32.5\%), and selecting sires with a lower percentage of stillbirths (29.2\%). The MIs not considered to be effective were: use of gloved-hands during calving assistance (76.6\%), washing the hands and udder before each milking (70.1\%), consulting ANHS providers about dairy cattle diseases prevention (68.8\%), and cull of persistently endometritis positive cows (67.5\%). The study revealed that neither dairying experience, poverty level, education level, nor the source of ANHS providers influenced $(p>$ 0.05) the considerations by farmers about the MIs.

The standardized scores illustrated in Fig. 2 represent the computed effectiveness scores assigned to each MI. The y-axis represents the effectiveness scores of all 20 MIs that were examined. The right of the $\mathrm{x}$-axis shows the MIs that were scored highly for effectiveness whereas the left of the $\mathrm{x}$-axis represents the MIs that were scored low for effectiveness.

Of the 20 MIs, $60.0 \%(n=12)$ were scored highly for effectiveness, and these are located in the upper righthand quadrant. These MIs belong to equipment-sharing between cows within farms and/or with neighbouring farms and hygiene in a cowshed (group 1 of MIs: 02, 04, and 10), control of breeding services (group 2 of MIs: 05, 14 and 19), animal health interventions (group 3 of MIs: 06 and 07), and reduce the risks of contamination within 


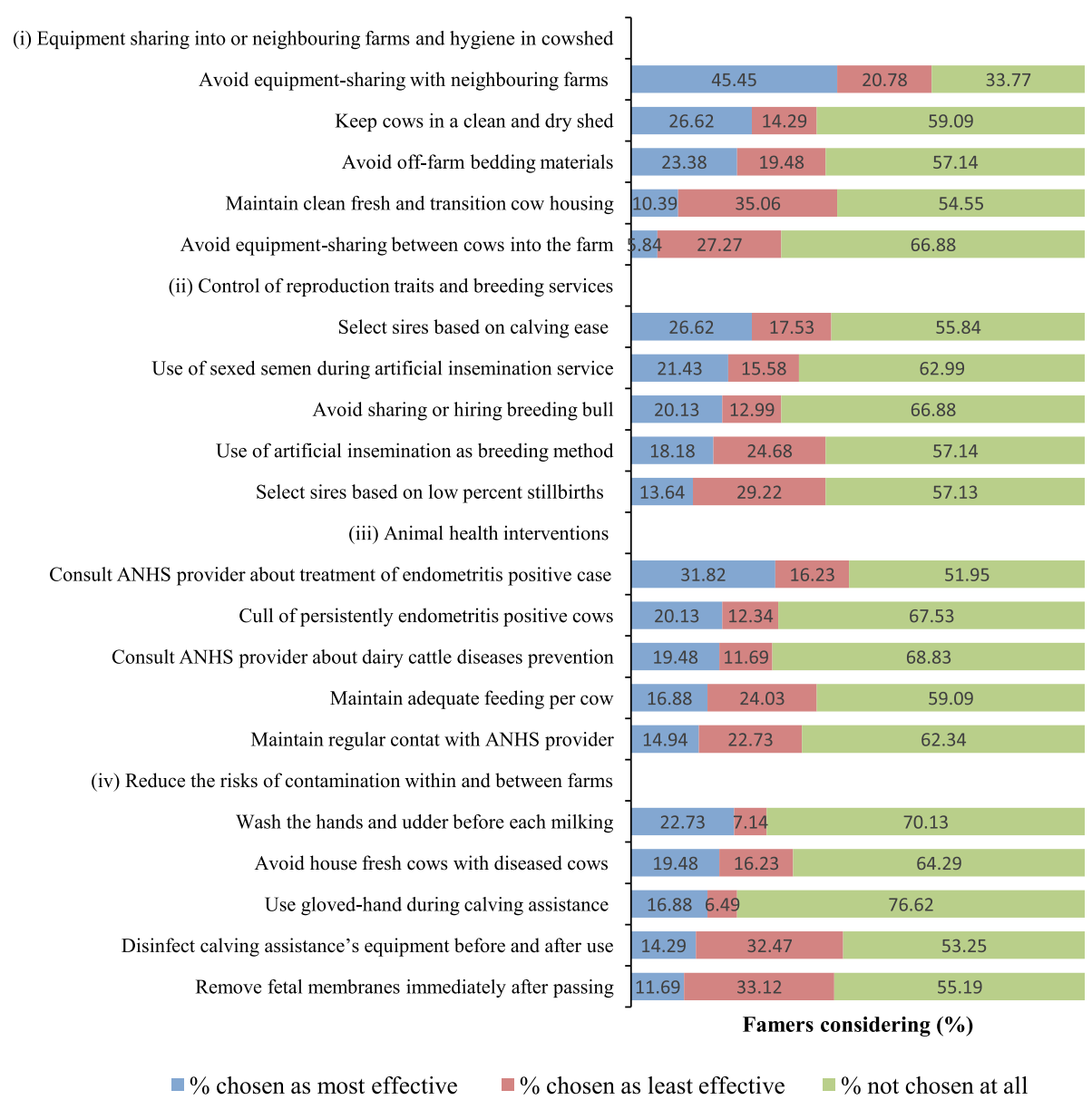

Fig. 1 Best-worst percentages of farmer's opinion on the effectiveness of 20 management interventions towards endometritis on dairy farms $(n=154) .{ }^{*} \mathrm{ANHS}=$ animal health service

and between farms (group 4 of MIs: 03, 09, 17 and 20). Based on standardized scores, $20,15,15$, and $10 \%$ of MIs were considered as the most effective MIs in group 4, 1, 2, and 3, respectively. Avoiding equipment sharing with neighbouring farms (MI 02), consulting ANHS provider about the treatment of positive endometritis case (MI 07), and washing the hands and udder before each milking (MI 20) were the perceived most effective MIs. However, there were no significant differences (Chi-square $=1.583, p=0.663$ ) found among the four groups of MIs.

The MIs scored low for effectiveness were: maintaining clean transition cow housing (MI 12), removing fetal membranes immediately after passing (MI 17), and avoiding equipment sharing between cows within the farm (MI 01).

\section{Discussion}

This study is a pioneer application of the best-worst scaling (BWS) method in analyzing farmers' perspectives on the effectiveness of different MIs in the prevention and control of endometritis among zerograzed dairy cows on smallholder farms. The approach has not been used previously in evaluating how dairy farmers perceive the effectiveness of different MIs for endometritis in dairy farms. The application of BWS method enabled the identification of $12(60.0 \%)$ most effective MIs and 8 (40.0\%) least effective MIs on smallholder farms practicing cut-and-carry feeding system in Rwanda.

As in the present study, the application of BWS with experts on opinion about the effectiveness of biosecurity measures on dairy farms informed livestock management practices in the United Kingdom [21]. In that study, preventing contact with neighbouring animals, and implementing rapid culling of persistently infected animals were rated the most effective biosecurity measures. In contrast, minimizing the number of visitors entering the farms, and avoiding equipment-sharing between farms were rated the least effective. Similarly, 
Avoid equipment-sharing with neighbouring farms

Consult ANHS providers about treatment of endometritis case

Wash the hands and udder before each milking

Keep cows in a clean and dry shed

Use gloves during calving assistance

Select sires based on calving ease

Disinfect calving assistance's equipment before and after use

Consult ANHS providers about the treatment and prevention of diseases

Avoid sharing or hiring breeding bull

Use a sexed semen during artificial insemination

Avoid off-farm bedding materials

Avoid housing fresh cows with diseased cows

Use an artificial insemination as breeding method

Maintain adequate feeding per cow

Maintain regular contat with ANHS providers

Select sires based on low percent stillbirths

Cull of persistently endometritis positive cows

Avoid equipment-sharing between cows into the farm

Remove fetal membranes immediately after passing

Maintain clean transition cow housing

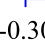

$-0.30$

0.20

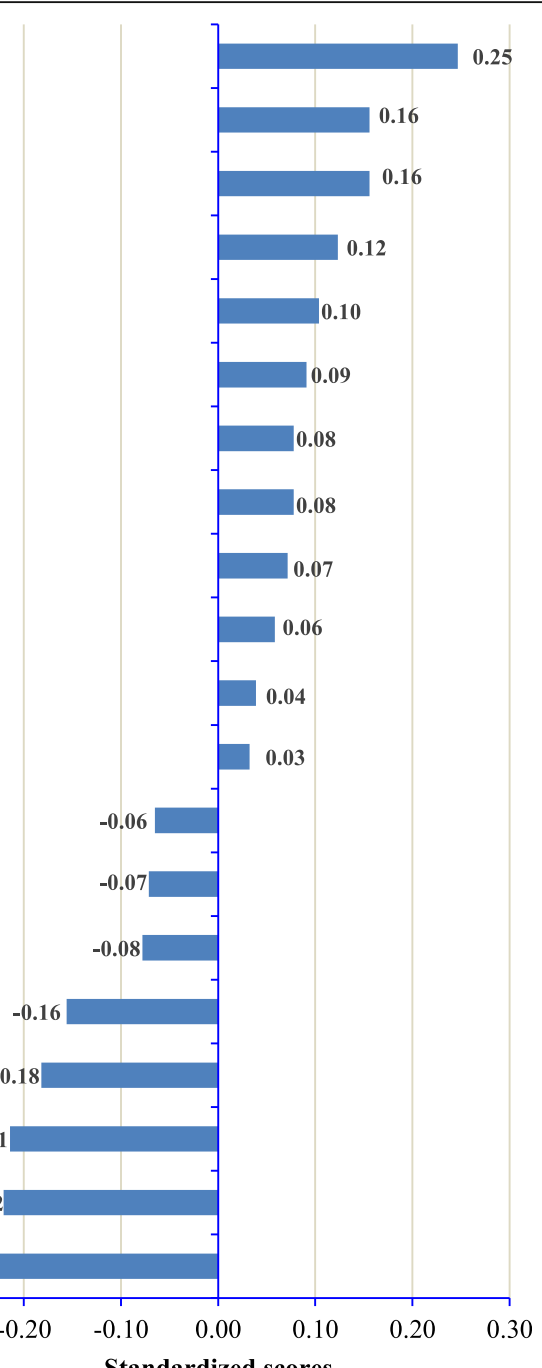

Fig. 2 Effectiveness scores for the 20 management interventions (MIs). *ANHS = animal health service

BWS was applied [26] to identify the effectiveness of intervention strategies for African swine fever in Western Europe. Findings suggest that the culling of all infected pigs and restricting movement for neighbouring farms were the most effective interventions to control the disease.

These findings reflect farmer experiences with MIs that effectively work for them. Farmer's experiences with MIs indicate that farmers require a basket of choices of management practices from which to choose what suits their farming circumstances. Their practical skills can be integrated into extension strategies and veterinary service delivery to farmers and research attention to enhance herd health management [22].

In the current study, MIs (02, 04, and 10) related to equipment-sharing within the farm or with neighbouring farms and hygiene in cowshed were scored the most effective for preventing and controlling endometritis in dairy farms. The practice of sharing or borrowing farm equipment can be a media of disease and/or pathogen transmission [28]. This finding corroborates with the observations [29] in the United Kingdom that sharing equipment and materials between farms without appropriate biosecurity measures increases the risk of microorganisms contamination or disease transmission.

Farmer consideration that clean and dry cowshed (MI 10) and avoiding off-farm bedding materials (MI 04) are effective for prevention and control of endometritis has implications on hygiene practices. It is an indication that it is crucial to practice frequent removal of any soiled or damp bedding before adding fresh bedding materials. On the sampled farms, this was practiced on average twice a week. Unhygienic bedding materials and heavily soiled cattle shed are potential risk factors for transmission of causal microorganisms for disease in postpartum cows, of which endometritis is a prevalent fertility 
disease [30, 31]. Furthermore, high mastitis prevalence (76.2\%) has been attributed [32] to inadequate biosecurity measures on zero-grazing dairy farms in Rwanda. Therefore, the implementation of biosecurity measures is essential to improving cow welfare as well as their production and fertility performance. This observation concurs with observations made in Ethiopia [33], in India [34], and in California, United States of America [35].

The MIs $(05,14$, and 19) related to the control of breeding services scored highly for effectiveness. In the sampled farms, over half were using shared bulls for service without precautions for potential risks of disease transmission. Farmers used bull service because breeding bulls were readily available and affordable within the communities and about twice cheaper compared to artificial insemination (AI) (\$3.3 vs. \$5.6 per service). However, the bulls or the cows on heat are moved from one place to another for mating. The bulls and cows are not pre-screened for diseases before use. This way, the bull mating practice presents a risk of transmitting reproductive diseases, endometritis included as corroborated by finding [36] in Nyagatare district, Rwanda, and the United Kingdom dairy herds [21].

Farmers using AI services can be advised by their AI technicians about the advantages of selecting sires with easy-calving and can be assisted in choosing AI semen for their cows. The birth of a male calf may increase the risk of dystocia cases [37]. In such cases, giving calving assistance may also increase the likelihood of trauma and contamination of the reproductive tract and increase the risk of endometritis infections. Farmers can reduce the risk of dystocia by using sexed semen from sires with calving ease and low percent stillbirths to produce female calves [38].

The MIs (06 and 07) related to animal health intervention scored highly for effectiveness, implying that proper veterinary service delivery is essential for farmers in the prevention and control of endometritis disease [39]. In Brazil [40], metabolic disorders are important in the transition period because they predispose cows to reproductive disorders. Mastitis disease is also a significant risk factor for endometritis [41]. Proper veterinary service delivery facilitates prompt veterinary intervention for these risk factors.

However, in the present study, hardly half of the farmers accessed ANHS from VETs, CAHWs or LTHs. Basically, ANHS providers visit dairy herds at farmer's request mostly when a health problem is noticed. In that case, the services offered target the diseases with commonly noticeable symptoms in dairy cows. Endometritis received less attention because the sampled farmers could not attribute the symptoms they observed to endometritis disease. This calls for capacity building program on endometritis diagnosis, extension advisory, and management on dairy farms to apply effective MIs for prevention and control of endometritis. This recommendation aligns with observation [20] in Uganda that improved extension service and advisory support in preand postpartum periods are effective ways to manage endometritis in the dairy herds.

Other MIs (03, 09, 17, and 20) that farmers considered highly effective for the prevention and control of endometritis related to reducing risks of contamination within and between farms. At high risk of contamination are fresh cows and cows with trauma in the reproductive tract because fresh cows are immunosuppressed, and housing them with mastitic cows exposes them to disease-causing pathogens [42]. Therefore, on-farm biosecurity measures are important to minimize the disease transmission in the dairy herds. Knowledge gaps might lead to widespread high-risk practices for both animals and humans [43]. From literature [42, 43], it is advisable to assist calving only when needed and always using gloved-hands, disinfecting calving equipment, and keeping cows in a clean cowshed and calving area to reduce trauma and contamination of female genital tract. Further, studies in France [44] and the United States of America [45] demonstrate the importance of good housing conditions, disinfection, and disease prevention in minimizing disease entry and spread within a dairy herd.

The adoption and implementation of the MIs that farmers perceived are most effective for the prevention and control of endometritis remain limited on the dairy farms in Rwanda. This situation applies as well to the United Kingdom [21] and Switzerland [46]. The reasons are likely related to some MIs being impractical to implement. This has to be addressed in in-depth research to enhance the practical application of MIs for the prevention and control of endometritis.

For the MIs that farmers considered the least effective for the prevention and control of endometritis, local contextual issues are likely to be at play. The sampled farmers had a low level of information about endometritis diagnosis and management; hence, could not have applied some of the MIs on their farms. Recent studies conducted in Switzerland [46] and Canada [47] showed that farmers' awareness of the disease and a better understanding of the transmission of disease influence their perceptions on the effectiveness of biosecurity measures. Another study [48] with Indian farmers indicated that knowledge gaps about cattle diseases and how to prevent them limited the adoption of animal genetic improvement and health care practices.

In the study area, the VETs cover a wide area in the mountainous region with many farmers to attend to, which hinders prompt access in remote areas. CAHWs and LTHs could serve the remotely accessible areas for better and timely service delivery to farmers. In 
Indonesia [49] and Ghana [50], studies concluded that insufficient VETs and lack of capital hindered farmers from accessing prompt veterinary services and adopting and implementing biosecurity measures. In Canada, a study indicated that farmers who discussed biosecurity measure with a VET were more likely to perceive biosecurity measure as more effective than farmers who did not [47]. This is an indication that it is the best practice that farmers regularly consult with the ANHS providers on a plan of dairy herd health management.

Of the sampled farmers, about a third had a cowshed without a roof, and therefore, cows are not protected from environmental stresses such as the muddy floor in the zero-grazing unit. This condition favors bacterial contamination, where disease management practices are not implemented. It is because of the association between the lack of implementation of disease management practices and the high prevalence of mastitis in the dairy herds $[32,51,52]$.

In Rwandan comprehensive wealth-ranking system criteria [53], the sample farmers were in the group classified as poor to very poor. Because they are the most vulnerable, resource-poor farmers, they have low capacity to implement the MIs [17]. This is corroborated [54] in Canadian dairy farms where a significant barrier to implementing prevention strategies for Johne's disease was the cost to build facilities, hire more labor, and purchase the recommended equipment. In the present study farms, the land size owned was a resource constraint to farmers, necessitating practicing cut-and-carry feeding system in crowded cowshed units, with poor standards of hygiene. This condition exposes cows to bacterial contamination [55].

\section{Conclusion}

This study has demonstrated the application of the BWS object case method in understanding the MIs that farmers consider are most effective in the prevention and control of endometritis disease in the dairy herds. The identified MIs can be prioritized for extension dissemination to farmers for effective prevention and control of endometritis disease. These are: avoiding sharing equipment with neighbouring farms, consulting animal health service provider about the treatment of endometritis cases, keeping cows in a clean and dry shed, and selecting sires based on calving ease. However, the MIs have to be applied in combination: no one of the MIs would be singly effective as there are multiple risk factors. In-depth research on these MIs is, however, necessary to enhance their practical application on smallholder dairy farms.

\section{Methods}

\section{Study area}

Data was collected from smallholder dairy farms with zerograzed cows in Gasabo district of Rwanda (Additional file 1).
The district is organized in 15 administrative sector units with 501 villages [56]. The study location lies at an altitude of 1800-m above sea level, with an annual mean temperature of $22^{\circ} \mathrm{C}$ and a bimodal rainfall pattern averaging $1000 \mathrm{~mm}$ annually [1]. The district was chosen because of more prevalent dairy zero-grazing farms than the other districts [57]. Under smallholder dairy zero-grazing conditions, muddy conditions are prevailing, hygienic standards are low, herd health management plan is absent [32], risk exposure to bacterial disease infections is high, and the likelihood of endometritis disease infections is high.

A minimum sample of 150 farmers was computed as necessary for the study from the application of formula [58]:

$$
n=\frac{Z_{1-\alpha / 2}^{2} p(1-p)}{d^{2}}
$$

Where

$n=$ sample size;

$Z_{1-\alpha / 2}=95 \%$ level of confidence (1.96);

$p=$ proportion of farmers aware of disease prevention and control, set at $11.0 \%$ [55];

$d=$ desired absolute precision level, set at alpha 0.05 .

\section{Survey design}

This cross-sectional study recruited 154 farmers through a snowball sampling procedure. Sector animal resource officers identified the initial farmers in the sampling process. The researchers visited these farmers and, through snowball sampling, identified other farmers with the help of initial farmers. The initial farmers had to meet defined criteria. One, being aware of at least one a symptom of endometritis disease in cows (delayed conception, abortion or vaginal purulent or mucopurulent discharge) observed in the herd within the past 1 year. Two, granting written informed consent to participate in the study. Three, the farm is accessible physically. All the recruited farmers were visited between September 2018 and April 2019.

The study used the best-worst scaling (BWS) object case method to gather the perspectives of the farm owner about the effectiveness of MIs for endometritis prevention and control $[21,59]$. This approach has been used for livestock disease management in many countries $[21,22,26]$. The BWS object case was applied to 20 MIs considered important in the prevention and control of endometritis (Table 3), based on the literature review $[12,14,19,60-63]$.

In this study, MIs was defined as an action that reduced or targeted risk factors for endometritis in the dairy herds. The effectiveness of MIs was the extent to which the MIs prevented or controlled endometritiscausing agents on-farm. 
Table 3 Management interventions (Mls) examined in the study

\begin{tabular}{|c|c|}
\hline $\begin{array}{l}\text { Mls* }^{*} \\
\text { codes }\end{array}$ & Management interventions (Mls) \\
\hline 1 & Avoid equipment-sharing between cows within the farm \\
\hline 2 & Avoid equipment-sharing with neighbouring farms \\
\hline 3 & $\begin{array}{l}\text { Avoid housing fresh cows with diseased cows or those } \\
\text { with chronic illnesses such as mastitis }\end{array}$ \\
\hline 4 & $\begin{array}{l}\text { Avoid off-farm bedding materials and maintain adequate } \\
\text { bedding materials per cow }\end{array}$ \\
\hline 5 & Avoid sharing or hiring a breeding bull \\
\hline 6 & $\begin{array}{l}\text { Consult ANHS* provider about the treatment and prevention } \\
\text { of mastitis and metabolic diseases }\end{array}$ \\
\hline 7 & $\begin{array}{l}\text { Consult ANHS* providers about the treatment of endometritis } \\
\text { positive cases }\end{array}$ \\
\hline 8 & Cull of persistently endometritis positive cows \\
\hline 9 & $\begin{array}{l}\text { Disinfect equipments used in calving assistance before and } \\
\text { after use }\end{array}$ \\
\hline 10 & Keep the cows in a clean and dry shed \\
\hline 11 & Maintain adequate feeding per cow \\
\hline 12 & Maintain a clean transition cow housing \\
\hline 13 & $\begin{array}{l}\text { Maintain regular contact with } \mathrm{ANHS}^{*} \text { providers for advisory } \\
\text { support on endometritis prevention in dairy farm }\end{array}$ \\
\hline 14 & Select sires based on calving ease \\
\hline 15 & Select sires based on low percent stillbirths \\
\hline 16 & Remove fetal membranes immediately after passing \\
\hline 17 & Use gloves during calving assistance \\
\hline 18 & Use an artificial insemination service \\
\hline 19 & Use a sexed semen during artificial insemination service \\
\hline 20 & Wash the hands and udder before each milking \\
\hline
\end{tabular}

*MIs Management interventions, ANHS Animal health service

The check-list for best-worst scaling choice was designed in Sawtooth Software (Version 8) [64] with defined criteria: (i) each MI appeared in an equal number of times in a different choice card; (ii) each MI paired with any other MI an equal number of times; (iii) each MI appeared four times in total across all choice cards and (iv) the order of MIs within each choice card was randomly assigned [64, 65].

The questionnaire was designed in such a way that each dairy farmer had to respond to a total of 16 choice cards of five MIs each. The questionnaire was developed in English (Additional file 2), and the researchers conducted the interviews in the local language (Kinyarwanda). The questionnaire was pre-tested on 30 farmers to ensure the objective of the study is clear, to determine the time needed to complete the survey per farmer and the obstacle that could arise, and to improve the clarity of the questions to respondents [66]. The 30 farmers used in the pre-testing survey were not part of the farmers recruited for the study being reported in this paper.
Subsequently, for each choice card, the farmer was asked to choose first the most effective and then the least effective MI for endometritis prevention and control (Table 4). To increase variation and combination of MIs across dairy farmers, the order of 16 choice cards was randomly assigned for each dairy farmer using Microsoft Office Excel (version 2016) [59]. The sociodemographic characteristics of each participating farm and farmer were recorded.

\section{Statistical analysis}

Data analysis of the best-worst choices were performed using two approaches: (i) best-worst percentages for the number of times each MI was selected as most effective, least effective or not chosen across a sequence of 16 choice cards divided by the availability of each MI; and (ii) best-worst score as the standardized score for each MI $[59,67]$. The score was computed as the difference between the number of times chosen as the most and least effective divided by the availability of each MI [59, 68]. The availability of each MI was computed as the number of times it has appeared in total across the 16 choice cards multiplied by the sample size [59, 69].

The computed standardized score indicates the effectiveness of $\mathrm{MI}$ on a scale from -1.0 to +1.0 . A positive score $(+1.0)$ indicates that the MI was chosen as most effective more often than as least effective. In contrast, the negative score $(-1.0)$ suggests that the MI was chosen as least effective more often than as most effective $[27,59]$. Thus, the higher the score, the more the MI was effective. In this study, different MIs were categorized into four-group endometritis prevention and control plan relating to (i) equipment-sharing between cows within farm and/or with neighbouring farms and hygiene in cowshed, (ii) control of breeding services, (iii) animal health interventions, and (iv) reduce the risks of contamination within and between farms.

Table 4 Example of an effectiveness best-worst scaling choice card used in the study

\begin{tabular}{|c|c|c|c|}
\hline Mls* codes & Management interventions (Mls) & $\begin{array}{l}\text { Most } \\
\text { effective }\end{array}$ & $\begin{array}{l}\text { Least } \\
\text { effective }\end{array}$ \\
\hline 2 & $\begin{array}{l}\text { Avoid equipment-sharing with } \\
\text { neighbouring farms }\end{array}$ & & \\
\hline 19 & $\begin{array}{l}\text { Use a sexed semen during } \\
\text { artificial insemination service }\end{array}$ & & \\
\hline 6 & $\begin{array}{l}\text { Consult } \text { ANHS }^{*} \text { providers about } \\
\text { the treatment and prevention } \\
\text { of mastitis and metabolic diseases }\end{array}$ & & \\
\hline 15 & $\begin{array}{l}\text { Select sires based on low percent } \\
\text { stillbirths by referring to dairy } \\
\text { sires catalogue }\end{array}$ & & \\
\hline 10 & Keep cows in a clean and dry shed & & \\
\hline
\end{tabular}

*MIs Management interventions, ANHS Animal health service provider 
Frequency distribution describing farmer characteristics was generated from cross-tabulation and frequency tested with Chi-square test statistics. Hypothesis testing was with the Non-parametric Kruskal-Wallis $\mathrm{H}$ test for whether the source of ANHS providers, education level, or poverty level differ by farmer's choices. A Binomial test was used to analyze the significance of the differences in cattle shed flooring (earthen or concrete), cattle shed types (covered with or without a roof), breeding services (artificial insemination or bull) and herds recording (not practiced or incomplete). All statistical analyses were performed in IBM SPSS Statistics 22.0 for Windows [70], and the statistical significance level was set at alpha $<0.05$.

\section{Supplementary information}

Supplementary information accompanies this paper at https://doi.org/10 1186/s12917-020-02368-6.

Additional file 1. Map of the study area. The additional file 1 illustrates the map for study setting, and authors generated it. During this study, GPS data were collected on the location of each farmer's household using GPS eTrex 10 Garmin. QGIS version 2.18.20-Las Palmas software was used to produce the map depicted in additional file 1 based on the GPS data. Attribution: GIS Layers: Humanitarian Data Exchange. https://www. data.humdata.org.

Additional file 2. Questionnaire used for the farmers' interviews. The additional file 2 illustrates the questionnaire for the research on the perception of farmers about Endometritis prevention and control measures for zero-grazed dairy cows on smallholder farms in Rwanda.

\section{Abbreviations}

ANHS: Animal Health Service; BWS: Best-Worst Scaling; CAHWs: CommunityBased Animal Health Workers; GDP: Gross Domestic Product; LTHs: Local Traditional Herbalists; MIs: Management Interventions; SPSS: Statistical Package for the Social Sciences; VETs: Veterinarians

\section{Acknowledgments}

The authors thank the Rwanda Agriculture and Animal Resources Development Board for field support. For data collection, the authors acknowledge full support from Animal Resources Officers, enumerators, and farmers.

\section{Authors' contributions}

PN, OBK, CAH and BOB designed the study. PN, CAH and BOB planned and carried out the data collection. PN and OBK analysed the data and drafted the manuscript. PN, OBK, $\mathrm{CAH}$ and $\mathrm{BOB}$ reviewed the manuscript and approved the final version of the manuscript.

\section{Funding}

This material is based upon work supported by the United States Agency for International Development, as part of the Feed the Future initiative, under the CGIAR Fund, award number BFS-G-11-00002, and the predecessor fund the Food Security and Crisis Mitigation II grant, award number EEM-G-00-0400013. The funder supported the fieldwork (data collection). However, the funder had no role in the design of the study, analysis, interpretation of data, and writing the manuscript.

\section{Availability of data and materials}

The questionnaire used is available (Additional file 2). Map of the study area is available (Additional file 1). The datasets used and/or analyzed during the current study are available from the corresponding author on reasonable request.

\section{Ethics approval and consent to participate}

Rwanda Agriculture and Animal Resources Development Board delivered the ethical approval for the study (Ref: N. 01.11/928/018/PK/HQ of 17/05/2018). Written informed consent was obtained from all farmer participants included in the study.

\section{Consent for publication}

Not applicable.

\section{Competing interests}

The authors declare that they have no competing interests.

Received: 17 January 2020 Accepted: 10 May 2020

Published online: 05 June 2020

\section{References}

1. Shapiro Bl, Getachew G, Solomon D, Nigussie K. Rwanda livestock master plan; 2017. http://extwprlegs1.fao.org/docs/pdf/rwa172923.pdf. Accessed 20 Dec 2018.

2. National Institute of Statistics Rwanda (NISR). Gross domestic product 2017-18; 2018. https://www.statistics.gov.rw/publication/gdp-nationalaccounts-fiscal-year-201718. Accessed 10 March 2020.

3. International Fund for Agricultural Development (IFAD). Rwanda dairy development project. Detailed design report; 2016. https://webapps.ifad. org/members/eb/118/docs/EB-2016-118-R-19-Project-design-report.pdf. Accessed 13 Nov 2018.

4. Food and Agriculture Organization of the United Nations (FAO). Milk and dairy products in human nutrition; 2013. http://www.fao.org/3/i3396e/i3396 e.pdf. Accessed 12 Feb 2020

5. Makuza R, Ntawubizi N, Kabera F. Adoption of artificial insemination Services in Dairy Cattle in Rwanda; case study of Kigali City. J Anim Sci Adv. 2016;6: 1685-91.

6. Manzi M, Rydhmer L, Ntawubizi M, Karege C, Strandberg E. Reproductive performance of Ankole cattle and its crossbreds in Rwanda. Trop Anim Health Prod. 2019:51:49-54

7. Rukundo JD, Gachuiri CK, Wanyoike MM. Productive and reproductive performance of dairy cows in Gicumbi district, Rwanda. Int J Agric Sci Vet Med. 2018;6:86-97.

8. Hussein MM, Goma A, Abdel-Halim BR, Abdallah M. Negative impact of metritis and endometritis on reproductive performance in dairy cattle. J Vet Med Res. 2017;24:266-76.

9. Sharma A, Singh M, Kumar P, Dogra PK. Relationship between body condition score, sub-clinical endometritis and milk yield of dairy cows after parturition. Indian J Anim Sci. 2019:89:1091-3.

10. Karstrup CC, Klitgaard K, Jensen TK, Agerholm JS, Pedersen HG. Presence of bacteria in the endometrium and placentomes of pregnant cows. Theriogenology. 2017;99:41-7.

11. Drillich M, Wagener K. Pathogenesis of uterine diseases in dairy cattle and implications for fertility. Anim Reprod. 2018;15:879-85.

12. Sheldon MI, Molinari PCC, Ormsby TJR, Bromfield JJ. Preventing postpartum uterine disease in dairy cattle depends on avoiding, tolerating and resisting pathogenic bacteria. Theriogenology. 2020. https://doi.org/10.1016/j. theriogenology.2020.01.017.

13. Wang ML, Liu MC, Xu J, An LG, Wang JF, Zhu YH. Uterine microbiota of dairy cows with clinical and subclinical endometritis. Front Microbiol. 2018;9: $1-11$

14. Ganaie BA, Sultan F, Dar RR, Ahmad F. Uterine infection in dairy animals and its ameliorative measures: a review. J Pharmacogn Phytochem. 2018;7:194-9.

15. Jeremejeva J, Orro T, Waldmann A, Aunapuu M, Blank I, Arend A, et al. Early versus late postpartum treatment of clinical endometritis in dairy cows using a combination of systemic administrations of ceftiofur with prostaglandin F2A. Vet Ir Zootech. 2016;74:9-13

16. Makki M, Ahmadi MR, Gheisari HR, Nazifi S. Cure rate of postpartum endometritis after different treatments in high produce dairy cows. Comp Clin Pathol. 2017;26:921-8.

17. Wolff C, Abigaba S, Sternberg LS. Ugandan cattle farmers' perceived needs of disease prevention and strategies to improve biosecurity. BMC Vet Res. 2019:15:1-11.

18. Renault V, Damiaans B, Sarrazin S, Humblet MF, Dewulf J, Saegerman C. Biosecurity practices in Belgian cattle farming: level of implementation, constraints and weaknesses. Transbound Emerg Dis. 2017;65:1246-61. 
19. Crowe MA, Hostens M, Opsomer G. Reproductive management in dairy cows - the future. Ir Vet J. 2018;71:1-13.

20. Tayebwa D, Bigirwa G, Byaruhanga J, Kasozi K. Prevalence of endometritis and its associated risk factors in dairy cattle of Central Uganda. Am J Exp Agric. 2015;7:155-62.

21. Shortall O, Green M, Brennan M, Wapenaar W, Kaler J. Exploring expert opinion on the practicality and effectiveness of biosecurity measures on dairy farms in the United Kingdom using choice modeling. J Dairy Sci. 2017;100:2225-39.

22. Hansson H, Lagerkvist CJ. Dairy farmers' use and non-use values in animal welfare: determining the empirical content and structure with anchored best-worst scaling. J Dairy Sci. 2016;99:579-92.

23. Nunes F, Madureira T, Oliveira JV, Madureira H. The consumer trail: Applying best-worst scaling to classical wine attributes. Wine Econ Policy. 2016;5:7886.

24. Cheung KL, Wijnen BFM, Hollin IL, Janssen EM, Bridges JF, Evers SMAA, et al. Using Best-Worst Scaling to Investigate Preferences in Health Care. Pharmacoeconomics. 2016:34:1195-209.

25. Shittu A, Kehinde M. Willingness to accept incentives for a shift to climate smart agriculture among smallholder farmers in Southwest and Northcentral Nigeria. Conf Int Assoc Agric Econ. 2018; Conf Int Assoc Agric Econ. 2018. https://doi.org/10.22004/ag.econ.275983.

26. Guinat C, Vergne T, Jurado-Diaz C, Sánchez-Vizcaíno JM, Dixon L, Pfeiffer DU. Effectiveness and practicality of control strategies for African swine fever: what do we really know? Vet Rec. 2017;180:97.

27. Jones AK, Jones DL, Edwards-Jones G, Cross P. Informing decision making in agricultural greenhouse gas mitigation policy: A Best-Worst Scaling survey of expert and farmer opinion in the sheep industry. Environ Sci Policy. 2013; 29:46-56.

28. Rossi G, De Leo GA, Pongolini S, Natalini S, Zarenghi L, Ricchi M, et al. The potential role of direct and indirect contacts on infection spread in dairy farm networks. PLoS Comput Biol. 2017;13:1-19.

29. Wapenaar W, Archer S, Remnant J, Murphy A. Control of infectious diseases in dairy cattle. 2017. p. 457-86.

30. Dufour S, Labrie J, Jacques M. The mastitis pathogens culture collection. Microbiol Resour Announc. 2019;8:18-9.

31. Adnane M, Kaidi R, Hanzen C, England GCW. Risk factors of clinical and subclinical endometritis in cattle: a review. Turkish J Vet Anim Sci. 2017;41: $1-11$.

32. Ndahetuye JB, Persson $Y$, Nyman AK, Tukei M, Ongol MP, Båge R. Aetiology and prevalence of subclinical mastitis in dairy herds in peri-urban areas of Kigali in Rwanda. Trop Anim Health Prod. 2019;51:2037-44.

33. Getie A, Hilemelekot M, Taye M, Wuletaw Z, Tesfa A. A survey on breeding practice, and productive performance of Simada Cattle in Tach Gayint District, Ethiopia. J Life Sci Biomed J homepage J Life Sci Biomed. 2015;5:171-80.

34. Dutta LJ, Nath KC, Deka BC, Bhuyan D, Borah P, Saikia GK, et al. Management conditions and their relationship with infertility in crossbred cows under field conditions. Biol Rhythm Res. 2019;1-7. https://doi.org/10. 1080/09291016.2019.1608727.

35. Espadamala A, Pallarés P, Lago A, Silva-del-Río N. Fresh-cow handling practices and methods for identification of health disorders on 45 dairy farms in California. J Dairy Sci. 2016;99:9319-33.

36. Mushonga B, Dusabe J, Kandiwa E, Bhebhe E, Habarugira G, Samkange A. Artificial Insemination in Nyagatare District: Level of Adoption and the Factors determining its Adoption. Alexandria J Vet Sci. 2017;55:1-7.

37. Yehualaw B, Bassazin G, Sewalem M, Mekonen B. Review on the peridisposing factors, causes and economic impact of dystocia in dairy cows. J Reprod Infertil 8. 2017:8:72-81.

38. Diers S, Heise J, Krebs T, Groenewold J, Tetens J. Effect of sexed semen on different production and functional traits in German Holsteins. Vet Anim Sci. 2020:9:100-1.

39. Sumner $\mathrm{CL}$, von Keyserlingk MAG, Weary DM. Perspectives of farmers and veterinarians concerning dairy cattle welfare. Anim Front. 2018;8:8-13.

40. Daros RR, Hötzel MJ, Bran JA, LeBlanc SJ, von Keyserlingk MAG. Prevalence and risk factors for transition period diseases in grazing dairy cows in Brazil. Prev Vet Med. 2017;145:16-22.

41. Bacha B, Regassa FG. Subclinical endometritis in Zebu x Friesian crossbred dairy cows: Its risk factors, association with subclinical mastitis and effect on reproductive performance. Trop Anim Health Prod. 2010;42:397-403.

42. Bradtmueller BA, Amaral-phillips DM,. Recommendations for managing fresh dairy cows. 2019. https://afs.ca.uky.edu/files/recommendations_for_ managing_fresh_dairy_cows.pdf. Accessed 23 Sept 2019.
43. Ruano MP, Aguayo MDZ. Study of knowledge about bovine brucellosis among people involved in the cattle supply chain in the province of Manabí, Ecuador. OIE Rev Sci Tech. 2017;36:917-34.

44. Duval JE, Bareille N, Fourichon C, Madouasse A, Vaarst M. Perceptions of French private veterinary practitioners' on their role in organic dairy farms and opportunities to improve their advisory services for organic dairy farmers. Prev Vet Med. 2016;133:10-21.

45. Havlin JM, Robinson PH, Garrett JE. Niacin feeding to fresh dairy cows: Immediate effects on health and milk production. Anim Prod Sci. 2017;57: 1069-78.

46. Kuster K, Cousin ME, Jemmi T, Schöpbach-Regula G, Magouras I. Expert opinion on the perceived effectiveness and importance of on-farm biosecurity measures for cattle and swine farms in Switzerland. PLoS One. 2015;10:1-17.

47. Denis-Robichaud J, Kelton DF, Bauman CA, Barkema HW, Keefe GP, Dubuc J. Biosecurity and herd health management practices on Canadian dairy farms. J Dairy Sci. 2019;102:9536-47.

48. Channappagouda B, Deekshit GV, Bharadwaja K, Mahesha SD. Constraints in adoption of scientific animal breeding and health care practices - farmers ' point of view. Int J Sci Environ. 2016;5:3435-9.

49. Lestari VS, Sirajuddin SN, Abdullah A. Constraints of biosecurity adoption on beef cattle farms. Eur J Sustain Dev. 2018;7:151-6.

50. Adams F, Kwasi OY. Determinants of small ruminant farmers decision to participate in veterinary services in Northern Ghana. J Vet Med Anim Heal. 2015;7:193-204.

51. Suleiman TS, Karimuribo ED, Mdegela RH. Prevalence of bovine subclinical mastitis and antibiotic susceptibility patterns of major mastitis pathogens isolated in Unguja island of Zanzibar, Tanzania. Trop Anim Health Prod. 2017:50:259-66.

52. Amer S, Gálvez FLA, Fukuda Y, Tada C, Jimenez IL, Valle WFM, et al. Prevalence and etiology of mastitis in dairy cattle in El Oro Province, Ecuador. J Vet Med Sci. 2018:80:861-8.

53. Cho S, Kim T. Determinants of poverty status in Rwanda. African Dev Rev. 2017;29:337-49.

54. Ritter C, Jansen J, Roche S, Kelton DF, Adams CL, Orsel K, et al. Invited review: determinants of farmers' adoption of management-based strategies for infectious disease prevention and control. J Dairy Sci. 2017;100:3329-47.

55. Mpatswenumugabo JP, Bebora LC, Gitao GC, Mobegi VA, Iraguha B, Kamana $\mathrm{O}$, et al. Prevalence of subclinical mastitis and distribution of pathogens in dairy farms of Rubavu and Nyabihu Districts, Rwanda. 2017;2017:1-8.

56. Gasabo District Development Plan (GDDP). District development plan (20132018). https://gasabo.gov.rw/fileadmin/_migrated/content_uploads/Gasabo_ DDP_2013-2018.pdf. Accessed 13 Mar 2019.

57. Ministry of Agriculture and Animal Resources (MINAGRI). National dairy strategy. 2013. https://www.minagri.gov.rw/fileadmin/user_upload/ documents/STRAT.PLC/2013_National_Dairy_Stratey.pdf. Accessed 23 Apr 2019

58. Bartlett JE, Kotrlik JW, Higgins CC. The organizational research: determining appropriate sample size in survey research. Inf Technol Learn Perform J. 2001;9:43-50.

59. Wittenberg E, Bharel M, Bridges JFP, Ward Z, Weinreb L. Using best-worst scaling to understand patient priorities: A case example of papanicolaou tests for homeless women. Ann Fam Med. 2016;14:359-64.

60. El-Khadrawy HH, Ahmed WM, Zaabal MM, Hanafi EM. Strategies for diagnosis and treatment of uterine infection in bovines. Glob Vet. 2015;15: 98-105.

61. Purohit GN, Ruhil S, Khichar V. Postpartum endometritis in dairy cows: current status of diagnosis, therapy and prevention. Theriogenology Insight - An Int J Reprod all Anim. 2015:5:1-23.

62. Gantner $V$, Bobić T, Potočnik K. Prevalence of metabolic disorders and effect on subsequent daily milk quantity and quality in Holstein cows. Arch Anim Breed. 2016;59:381-6.

63. Denis-Robichaud J, Kelton DF, Bauman CA, Barkema HW, Keefe GP, Dubuc J. Canadian dairy farmers' perception of the efficacy of biosecurity practices. J Dairy Sci. 2019;102:10657-69.

64. Sawtooth Software. The MaxDiff/Web Technical Paper, v8.0. Orem: Sawtooth Software, Inc.; 2013. https://www.sawtoothsoftware.com/. Accessed 17 July 2018

65. Orme B. How Good Is Best-Worst Scaling? 2018. https://www. sawtoothsoftware.com/support/knowledge-base/general-issues/175- 
support/technical-papers/maxdiff-best-worst-scaling/2013-how-good-is-bestworst-scaling. Accessed 20 July 2018.

66. Perneger TV, Courvoisier DS, Hudelson PM, Gayet-Ageron A. Sample size for pre-tests of questionnaires. Qual Life Res. 2015;24:147-51.

67. University of Technology Sydeny: Centre for the Study of Choice (UTS: CenSoc). Best-Worst Scaling (MaxDiff). 2018. https://www.uts.edu.au/sites/ default/files/CenSoC_BestWorstScaling_Overview.pdf. Accessed 20 July 2018.

68. Costanigro M, Deselnicu O, McFadden DT. Product differentiation via corporate social responsibility: consumer priorities and the mediating role of food labels. Agric Human Values. 2015;33:597-609.

69. Marley AAJ, Flynn TN. Best worst scaling: theory and practice. Int Encycl Soc Behav Sci Second Ed. 2015;548-52.

70. SPSS. Statistical Package for the Social Sciences. Version 22.0 for Windows. 2013. User's Guide. https://www.ibm.com/support/pages/ibm-spssstatistics-22-documentation\#en. Accessed 17 May 2019.

\section{Publisher's Note}

Springer Nature remains neutral with regard to jurisdictional claims in published maps and institutional affiliations.

Ready to submit your research? Choose BMC and benefit from:

- fast, convenient online submission

- thorough peer review by experienced researchers in your field

- rapid publication on acceptance

- support for research data, including large and complex data types

- gold Open Access which fosters wider collaboration and increased citations

- maximum visibility for your research: over $100 \mathrm{M}$ website views per year

At BMC, research is always in progress.

Learn more biomedcentral.com/submissions 